\title{
Retracted: Luciferase-transfected colon adenocarcinoma cell line (DLD-1) for use in Orthotopic Xenotransplantation studies
}

\author{
Muhammad Rashid Siddique ${ }^{1 \dagger}$, Steve Shynder ${ }^{1 \dagger}$, Muhammad Aqeel Ashraf ${ }^{2 *}$, Ismail Yusoff ${ }^{3}$ and Abdul Wajid ${ }^{4}$
}

A retraction article was published for this article. It is available from the following link; http://journal. chemistrycentral.com/content/6/1/121.

\begin{abstract}
Background: Renilla Luciferase reporter gene (rLuc) GL4.82 and GL4.13 promoter are key player in transfection, but precise knowledge of its targets in colon cancer remains limited. The aim of this study was to characterize the best transfection technique to produce a stable transfected colon DLD1 (colorectal adenocarcinoma cell line), therefore imaging based approaches were employed.

Results: DLD1 cells were transfected with a Plasmid (SV40-RLuc) carrying Renilla luciferase under the control of the SV-40 promoter, by using two different transfection techniques. Cells expressing the required DNA were isolated after antibiotic (Puramycin) selection. Clones of DLD-1/SV40-RLuc were produced using two different techniques (96 well plates and Petri dish) and their florescence intensity was recorded using IVIS machine (Calliper Life Sciences, Hopkinton, USA). Both techniques were characterized with the help of serial dilution technique. Results from this study substantiated that electroporation is the best. As expected, clones varied in their specific luciferase activity along with the dilutions. With the increase in cell concentration increase in intensity of florescence was recorded.

Conclusions: Based on the results we are confident that this transfected cell line DLD-1/SV40-RLuc (colorectal adenocarcinoma cell line) is the best for further Orthotopic Xenotransplantation Studies and in-vivo experiments as well. Investigation shows that DLD1/SV-rLuc cells have gained little bit resistance against both drugs therefore further study is suggested to know the reasons.
\end{abstract}

Keywords: DLD1, Reporter gene, Electroporation, ExGen transfection, MTT assay

\section{Background}

Human body is a complex of billions of cells, which grow, divide, and die in programmed fashion, and when any of these designed fashion undergoes uncontrolled or abnormal causes cancer. Cancer is a lethal disease; in 2007, 1554845 cancer related deaths were recorded in UK [1]. Good News is that despite increase in incidence, cancer mortality is decreasing [2] yet there is great need of new drug discovery and development. Drug discovery and development procedure involves; acquisition, preclinical screening, production and formulation,

\footnotetext{
* Correspondence: chemaqeel@gmail.com

${ }^{\dagger}$ Equal contributors

${ }^{2}$ Department of Chemistry, University of Malaya, 50603 Kuala Lumpur, Malaysia Full list of author information is available at the end of the article
}

toxicology, clinical trials, and general medical practice [3]. Screening drugs for their intracellular effects is a crucial part of the drug discovery and development process. To support any investigational new drug, there is an essential need of carefully designed preclinical drug in vitro and in vivo studies. Most of the researchers in drug development agree that the demonstration of anti-tumor efficacy in preclinical, typically animal based model of cancer is a key determinant in both, and compounds for testing should have shown target biomarker modulation in vitro and in vivo [4].

From 1950s to 1970s syngeneic murine models were used. Subcutaneous transplantation of human tumor xenograft in nude mice was used in next decades and now with the advancement of transgenic knock out models, interest
(C) Chemistry Central

(c) 2012 Siddique et al.; licensee Chemistry Central Ltd. This is an Open Access article distributed under the terms of the Creative Commons Attribution License (http://creativecommons.org/licenses/by/2.0), which permits unrestricted use, distribution, and reproduction in any medium, provided the original work is properly cited. 
in using genetically engineered mouse models (GEMMS) has sparked [5]. While syngeneic murine tumor models remain valuable for studying immunotherapeutic or targeting metastasis, the human tumor xenograft models established by inoculation of human cancer cell lines into the mice, which is immunodeficient, have been used for test of cytotoxic anticancer agents and new antineoplastic treatment modalities [6]. Since early 1990 new drug developments have moved from general cytotoxic agents to molecular target directed therapeutic, eventually, there was a need to identify tumor types and individual patient tumors that express the target and could benefit from therapies in clinical trials, therefore in vivo models used in preclinical development should be oriented, disease-to-disease or target directed [7]. This is still less clear and point of debate that which is the best model to use with respect to predict for clinical trails? Currently, nine out of ten experimental drugs fail in clinical studies because we cannot accurately predict how they will behave in people based on laboratory and animal studies. In Biomedical sciences use of animals as models to help understand and predict responses in humans, in toxicology and pharmacology in particular remains both the major tool for biomedical advances and a source of significant controversy [8].

During 19th century rise in use of animals rose up critically, which induced pressure on British government to amend Cruelty to Animal Act of 1876 in 1986 [9]. Recent developments of new techniques have permitted researchers to minimize the use of animals at a certain level. It has been very important element in the current success of biomedical research. Very first example of this was in the development of polio vaccine [10]. Since then human and animal cells culture techniques have improved greatly. Anyhow alternatives are nothing but new techniques that may lead to reduce the use of animal in research e.g. paper chromatography, radioimmunoassay, non-invasive imaging and use of Orthotopic models etc. has been main factor behind rapid development of biomedical research [11].

Currently research directions are towards specific cancer target, due to advanced development in cancer biology scientists are also focusing towards translational medicine and diagnosis. In use mouse tumor models have been improved in reliability of imitating human disease. Orthotopic implantation (Organ-specific) reproduces human tumor and metastasis, which has replaced ectopic subcutaneous implantation in experiments [12]. In Orthotopic models strong fluorescent are labeled with green fluorescent protein along with video detectors, allows the monitoring of details of growth, angiogenesis, and metastasis. External imaging is limited by light scattering in deep tissues, especially inside the skin. Signal reduction is markedly eradicated by opening a reversible skin-flap in the light path, which increases the detection sensitivity at much higher extent [13]. The problem of this technique depth of tissue is thereby minimized and many tumors that were previously hidden are now clearly observable [14]. In recent years, a significant development has been made in the choice of imaging cancer non-invasively in murine tumor models. This includes new materials that are imaging probes, which selectively accumulate in tumors, or that become activated by tumor-specific molecules in animal experimentation [15]. Other tumor imaging's techniques that rely upon the detection of gene expression (reporter) in the body of the animals have been developed [16], which made a significant impact on both the versatility and the specificity of tumor imaging of animals.

Optical imaging is rapidly developing field of research aimed at non-invasively interrogates animals for disease progression, evaluating the effects of a drug, assessing the pharmacokinetics behavior of a drug, or identifying molecular biomarker of disease. Optical imaging is mainly based on quantifying the qualitative changes in the emission of light by bioluminescence and fluorescence, which requires incorporation of a vector reporter gene into the cells [17]. In fluorescence imaging, fluorescently tagged agent is injected in mice which carry cells or tissue expressing a florescent transgene, imaged using different light tight highly sensitive CCD camera [18]. Bioluminescence imaging is based upon the sensitive detection of visible light that is produced during enzyme mediated oxidation of a molecular substrate when that enzyme is expressed in animals as molecular reporter [19].

There are several other optical techniques being developed, as FTIR Spectroscopy, Raman Spectroscopy and Multiphoton Imaging but, very low cost and high throughput capability of Bioluminescence imaging and Fluorescence imaging make these important to the drug discovery and development process [20,21]. Key to noninvasive imaging is to incorporation of these reporter genes (talked above) in to the cells "Transfection". Transfection is the introduction of foreign DNA into eukaryotic or prokaryotic cells [22]. It is the delivery of DNA, mRNA, proteins, and macromolecules into the cells. Goal for the transfection is to study the regulation of gene as well as protein expression and function [23]. Frederick Griffith, 1928 first transformed nonpathogenic pneumococcus bacteria into virulent variety by mixing nonpathogenic pneumococcus with heat-killed pathogenic bacteria. Avery, et al., 1944 reported that the pure DNA is originally the transforming factor [24]. There are different methods of transfection commonly used such as DEAE-dextran for the delivery of nucleic acids into cells for transient transfection [25], calcium phosphate for transient and stable both type of transfection of a 
variety of cell types [26], lipofection is much reproducible and efficient than other transfection modalities [27], microinjection for the introduction of functional proteins, genes, inhibitors of enzyme activities and antibodies into living cells [28], protoplast fusion is very efficient with high level of transfection about $10 \%$ [29], electroporation is proven to be efficient method for transfection of many cell types [30] though it requires very precise and accurate setting for duration and strength of the current for each type of the cells used and ExGen 500 used both in-vitro and in- vivo, and wide range of cell types can be transfected with this reagent [31]. It has shown very higher transfection efficiencies as compared to other cationic lipids and polymers [32,33].

The objective of this study was to develop a stable transfected cell line DLD-1 colon adenocarcinoma and at the same time characterize two different techniques of transfection on the basis of their efficacy. Characterize these transfected cells on the basis of their growth and chemo sensitivity to two standard drugs (Doxorubicin, MB2) for further use in orthotopic xenotransplantation studies.

\section{Results}

\section{Characterization of the techniques}

DLD1 cells were transfected with a SV40-RLuc carrying Renilla luciferase under the control of the SV-40 promoter, using two different techniques. Cells expressing the required DNA vector (Figure 1) were isolated using antibiotic selection method [3]. To characterize the best technique among both techniques used for transfection (ExGen500 and Electroporation) in this study, substrate coelenterazine $50 \mu \mathrm{g} / \mathrm{ml}$ was added to each well and output was recorded, using IVIS machine with in 10 second of the substrate addition. Electroporation and ExGen500 technique, Electroporation was found the best [3] shows, as ELec1's output was recorded $5.77 \times 10^{5} \mathrm{p} / \mathrm{sec} / \mathrm{cm} 2 / \mathrm{sr}$ while ExGen2's output was recorded $3.46 \times 10^{5} \mathrm{p} / \mathrm{sec} / \mathrm{cm} 2 / \mathrm{sr}$. While from ExGen1, 2, and 3 ExGen 2 was the best and from ELec1 and 2, ELec1 was found the best. As expected, clones varied in their specific luciferase activity (measured by standard luminometer -data not shown-). Figure 2 represents light emission in live cells corresponding to five different clones after the treatment of cells with the substrate $50 \mu \mathrm{g} / \mathrm{ml}$ Coelenterazine.

\section{Bioluminescence intensity is directly proportional to cell concentration}

Following selection of the best clones serial dilutions were prepared to show correlation between cell number and photon output. Bioluminescence intensity of FLuc serial dilutions was recorded using IVIS machine. It was found that bioluminescence intensity of FLuc cells increases in a gradual manner, with the increase in cell concentration. At the concentration of $1 \times 10^{5}$ cells/well it shows an output of $1.52 \times 10^{4}(\mathrm{p} / \mathrm{sec} / \mathrm{cm} 2 / \mathrm{sr})$. While a slight decrease has been noticed in the intensity of light at $5 \times 10^{5}$ cells $/ \mathrm{ml}$ where it shows $1.02 \times 10^{4}(\mathrm{p} / \mathrm{sec} / \mathrm{cm} 2 / \mathrm{sr})$ (Figure 3$)$. Results were measured (mean \pm s.d). All types of rLuc cells were serial diluted and treated with substrate. Results showed that bioluminescence intensity of the ELec1 increases in a gradual manner with the increase in cell concentrations, while ExGen 1 and 2 did not show gradual increase in the light emission. On the other hand ExGen3 showed very higheroutput of $4.70 \times 10^{5}(\mathrm{p} / \mathrm{sec} / \mathrm{cm} 2 / \mathrm{sr})$ (Figure 4$)$ at the concentration of $5 \times 10^{5}$ cells $/ \mathrm{ml}$ while at $1 \times 10^{6}$ cells $/ \mathrm{ml}$, it showed a decrease in the output $3.67 \times 10^{5}(\mathrm{p} / \mathrm{sec} / \mathrm{cm} 2 / \mathrm{sr})$ (Figure 4). Anyhow ExGen2 showed consistent increase

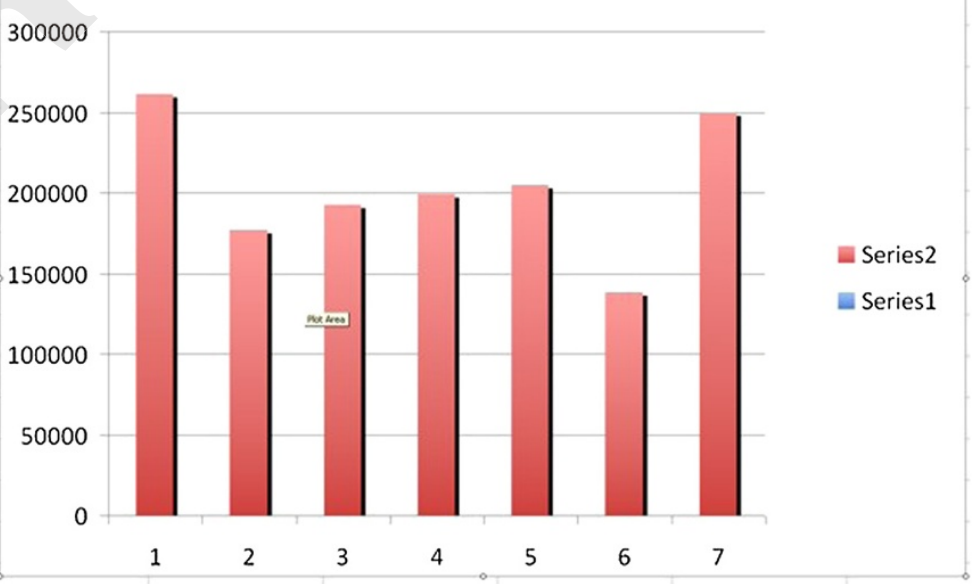

Figure 1 Cloning of SV40 region from GL4.13 into Nhe1 \& Hind III site of GL4.82 produces SV40-RLuc. 


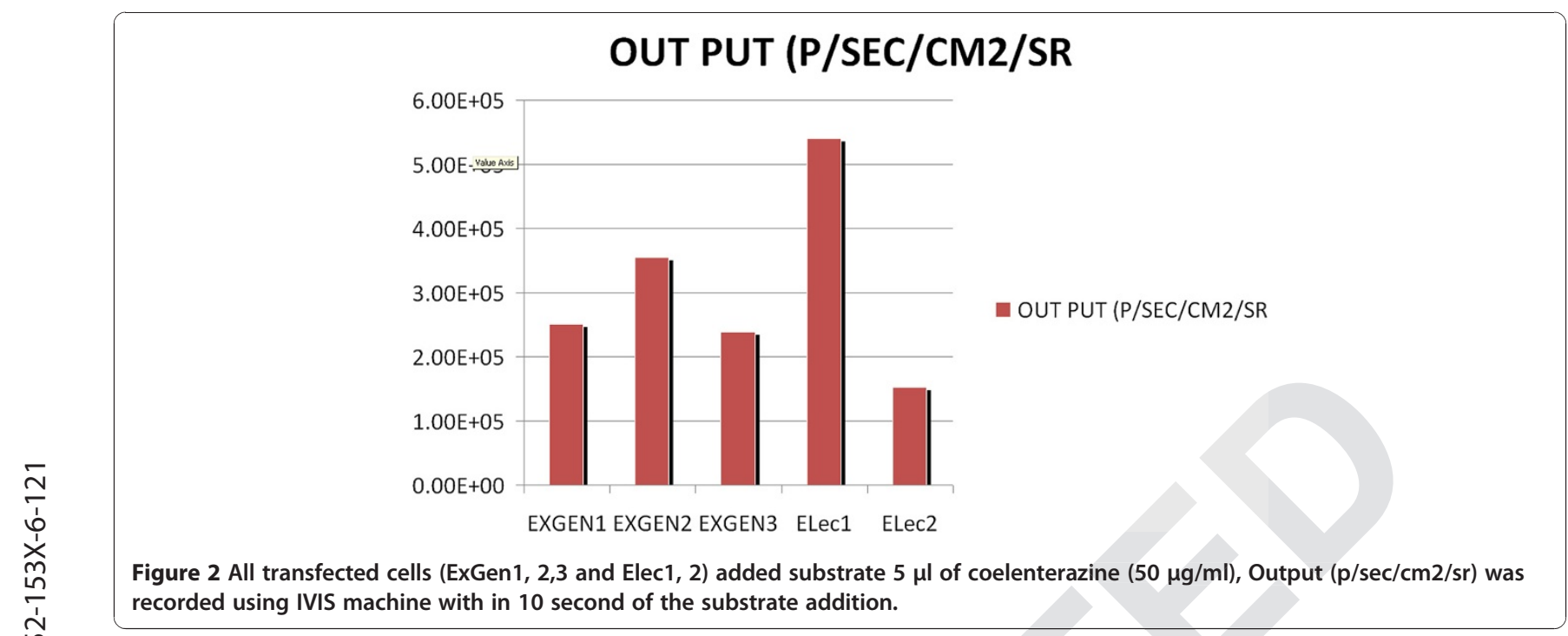

in output with higher concentrations of cells, $2.86 \times$ $10^{5}(\mathrm{p} / \mathrm{sec} / \mathrm{cm} 2 / \mathrm{sr})$ at $1 \times 10^{6}$ cells $/ \mathrm{ml}$. ELec1 was found producing highest intensity than any other one, showing $6.12 \times 10^{5}(\mathrm{p} / \mathrm{sec} / \mathrm{cm} 2 / \mathrm{sr})$ at $1 \times 10^{6}$ cells $/ \mathrm{ml}$.

\section{Characterization on the basis of cloning} 96 well cloning

After the selection of best clones, we also evaluated the cloning techniques between 96 well plate cloning and ring cloning, single cell clones of ELec1 (Best transfected cells) from 96 well plates were imaged directly. As expected, clones varied in their specific luciferase activity. We selected 7 best clones (Figure 5) on the bases of their light emission ranging from $1.384 \times 10^{5}$ to $2.612 \times 10^{5}(\mathrm{p} / \mathrm{sec} / \mathrm{cm} 2 / \mathrm{sr})$. In (Figure 5) it represents light emission in living cells corresponding to 7 clones after the treatment of cells with $25 \mu \mathrm{g} / \mathrm{ml}$ Coelenterazine.

\section{Ring cloning}

In case of ring cloning we selected ELec1 and ExGen2 to image. Results shown in (Figure 6) light intensity of ELec1 ranging from $4 \times 10^{5}$ to $1.57 \times 10^{6}(\mathrm{p} / \mathrm{sec} / \mathrm{cm} 2 / \mathrm{sr})$, and of ExGen2 it ranges from $1 \times 10^{5}$ to $1.275 \times 10^{6}$ $(\mathrm{p} / \mathrm{sec} / \mathrm{cm} 2 / \mathrm{sr})$. Three best resulting clones from ring cloning were selected for further process.

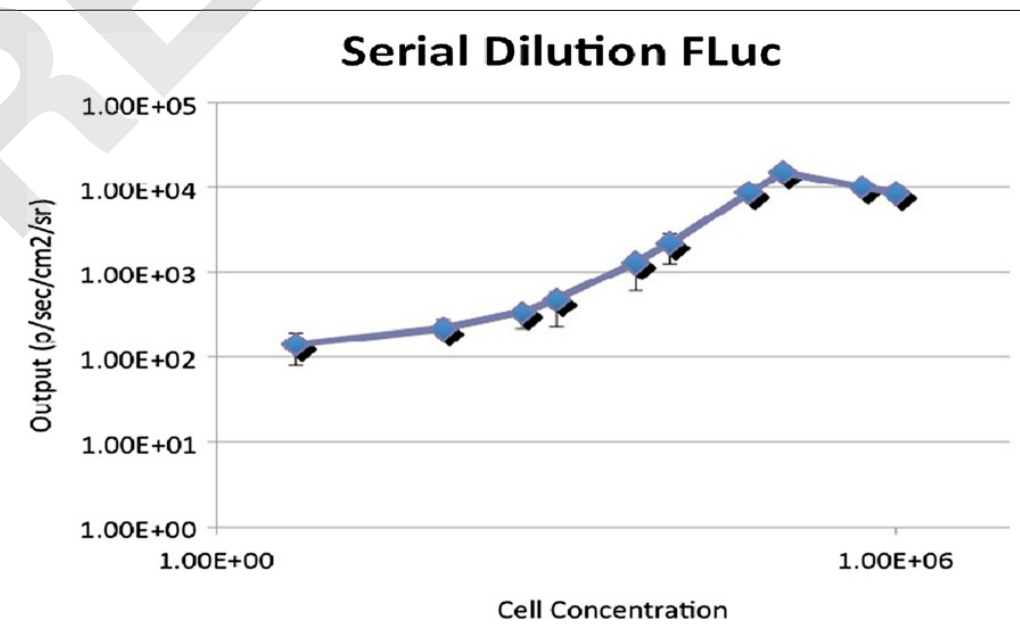

Figure 3 FLuc cells plated at range of concentration from $5 \times 10$ cells/well to from $1 \times 10^{6}$ cells/well, treated with $30 \mathrm{mg} / \mathrm{ml} \mathrm{D-Luciferin}$ at 1:200 dilution and Imaged using IVIS machine. Shows highest intensity of light at the concentration of $1 \times 10^{5}$ cells/well. Results were measured (mean $\pm \mathrm{sd}$ ). 

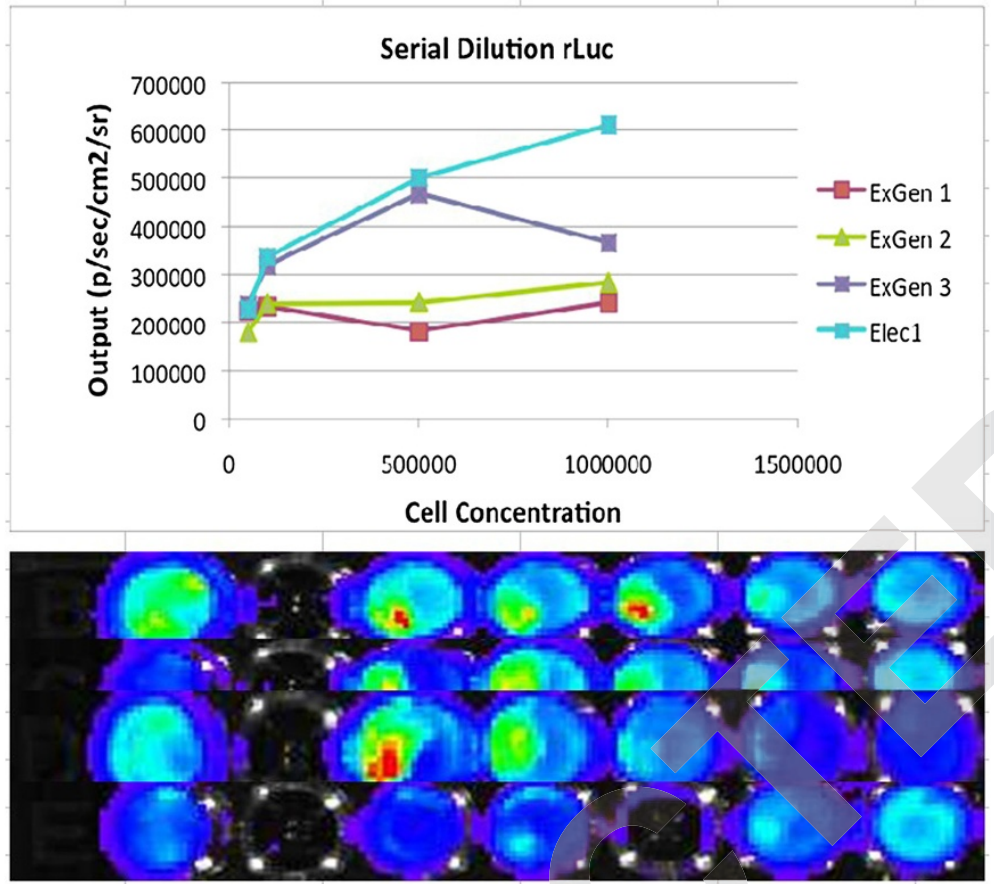

Figure 4 Three independent DLD1/SV-rLuc/ExGen and Two independent DLD1/SV-rLuc/ELec clones were seeded in 96-well plates at different cell densities, ranging from $5 \times 10$ cells/well to $1 \times 10^{6}$ cells/well and treated with the Renilla luciferase substrate Coelenterazine. $50 \mu \mathrm{g} / \mathrm{ml}$, output ( $\mathrm{p} / \mathrm{sec} / \mathrm{cm} 2 / \mathrm{sr}$ ) was recorded using IVIS machine with in 10 second of the substrate addition.

\section{Growth curve results}

To ensure that transfected cell shows no difference in their proliferation activity after transfection, we determined growth curve for Normal DLD1, FLuc, rLuc cells, results shown in (Figure 7). Following subculture, the control cells progressed through a characteristic growth cycle, nearing the peak phase at Day4. Normal DLD1 cells along with the other transfected cells, Fluc and rLuc, were cultivated at the concentration of $5 \times 10^{4} \mathrm{cell} / \mathrm{ml}$. Growth of all cells appears to be very similar with Fluc having the highest rate of

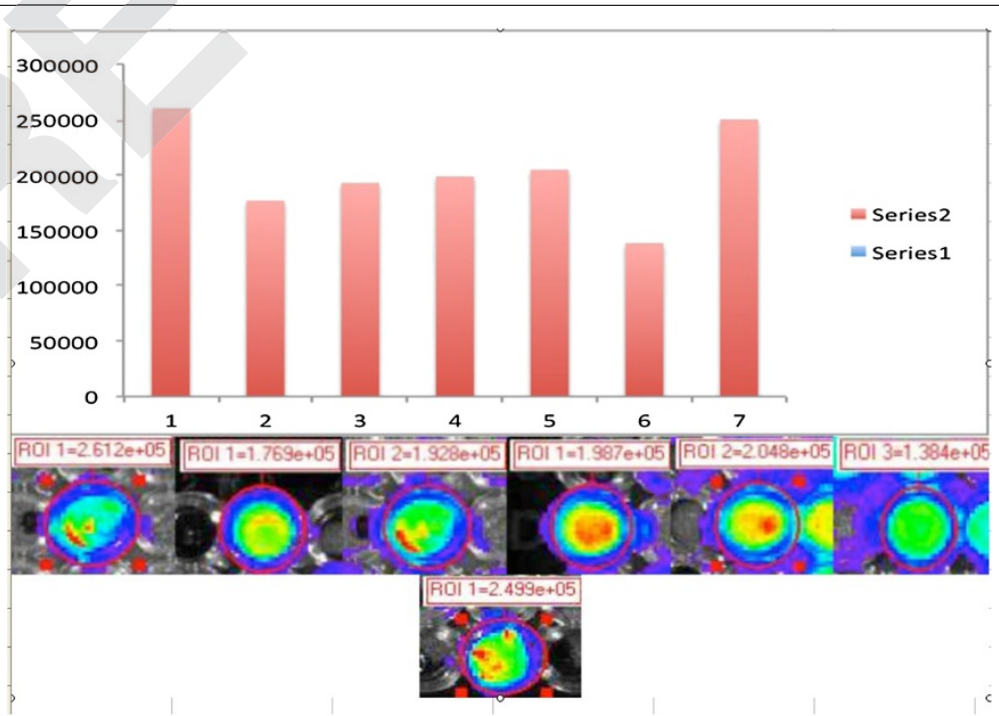

Figure 5 Seven independent DLD1/SV-rLuc/ELec clones were selected after seeding of 10 cells $/ \mathrm{ml}$ in 96 -well plates and treated with coelenterazine $25 \mu \mathrm{g} / \mathrm{ml}$ after overnight incubation. Output ( $\mathrm{p} / \mathrm{sec} / \mathrm{cm} 2 / \mathrm{sr}$ ) was immediately quantified using IVIS machine. 


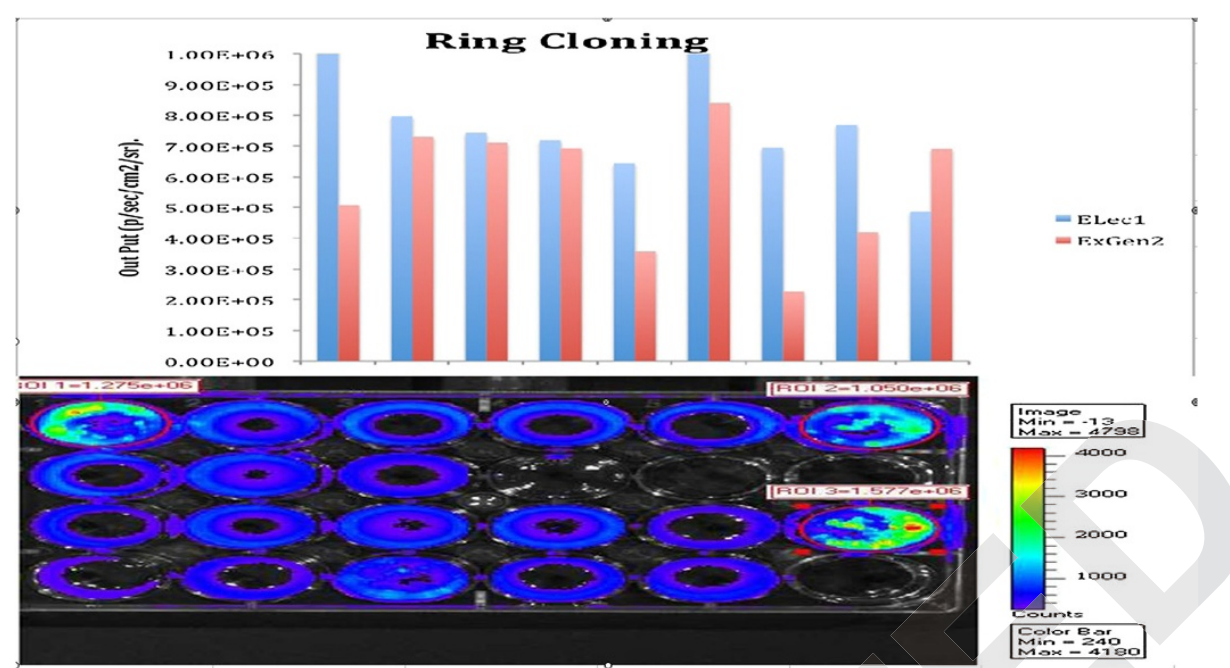

Figure 6 Nine independent clones of DLD1/SV-rLuc/ExGen2 and of DLD1/SV-rLuc/ELec1 were transferred from patri dishes to the 24-well plates at and treated with coelenterazine $25 \boldsymbol{\mu g} / \mathrm{ml}$ after overnight incubation. Output ( $\mathrm{p} / \mathrm{sec} / \mathrm{cm} 2 / \mathrm{sr})$ was immediately quantified using IVIS machine.

growth as compare to others. All the cells have shown nearly same trend of growth.

\section{MTT ASSAY}

In vitro growth inhibition by MB2 (ICT in-house drug) and Doxorubicin was tested against all the cell types wild type DLD1 and transfected DLD1/SV-FLuc, DLD1/ SV-rLuc cells, to ensure that transfected cells have no change in their response to drug as compared to normal DLD-1 cells. Cells were tested after 96 hours of drug exposure. Data was recorded by using Teacan reader set at the $540 \mathrm{~nm}$ filter. Results (Figures 8 and 9) described that DLD1/SV-rLuc transfected cells have gained little bit resistant against both of the drugs as ic50 for normal DLD-1 cells for MB2 is (30 nM +/-10 nM), for DLD1/ SV-FLuc $=(30 \mathrm{nM}+/-10 \mathrm{nM})$ and DLD1/SV-rLuc $=$ (100 nM +/- $30 \mathrm{nM}$ ) (Figure 4). Ic50 of DLD1 cells for doxorubicin is $=(100 \mathrm{nM}+/-30 \mathrm{nM})$ (Figure 6) and of DLD1/SV-FLuc $=(100 \mathrm{nM}+/-30 \mathrm{nM})$ and DLD1/SVrLuc $=(300 \mathrm{nM}+/-100 \mathrm{nM})$ was observed. Anyhow all cell types have shown more or less same behavior to the drug exposure. With increase in drug concentration, all cells have shown gradual decay in percentage viability. Results were measured as (mean \pm s.d).

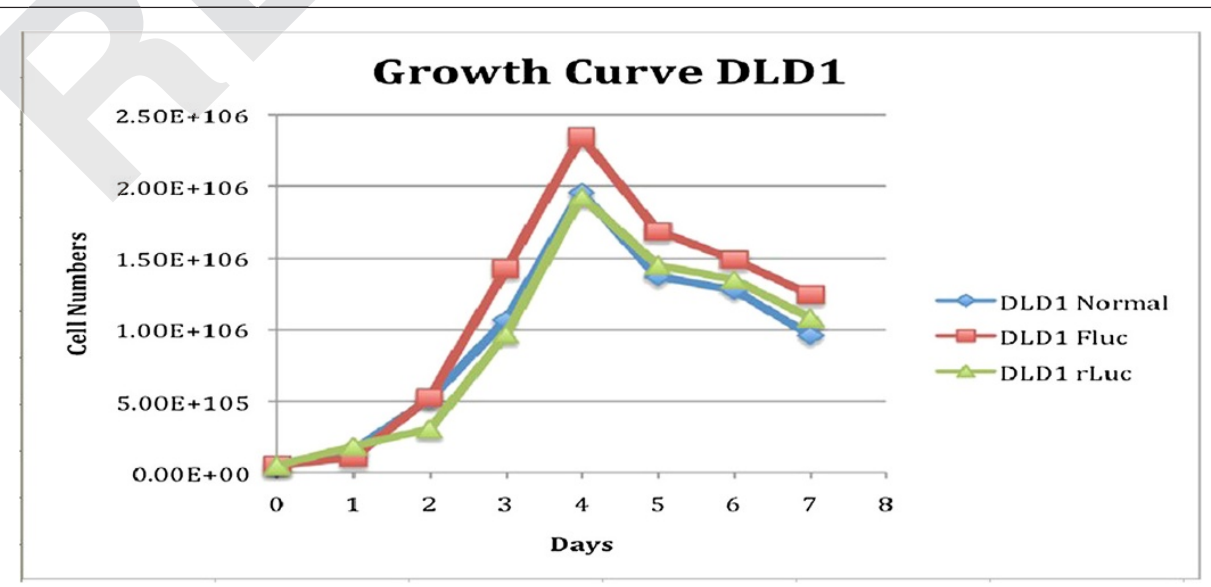

Figure 7 Above showing growth curve of Normal DLD1, DLD1/SV-FLuc, rLuc cells over the period of seven days. Cells were maintained in $10 \mathrm{ml} \mathrm{RPMl} \mathrm{supplemented} \mathrm{with} \mathrm{1 \%} \mathrm{L-glutamine,} \mathrm{1 \%} \mathrm{Sodium} \mathrm{Pyruvate,} \mathrm{and} \mathrm{5 \%} \mathrm{Fetal} \mathrm{bovine} \mathrm{syrup} \mathrm{(FBS),} \mathrm{incubated} \mathrm{at} 37^{\circ} \mathrm{C} 5 \% \mathrm{CO} 2$. Counted manually using haemocytometer. Results were measured (mean \pm s.d). 


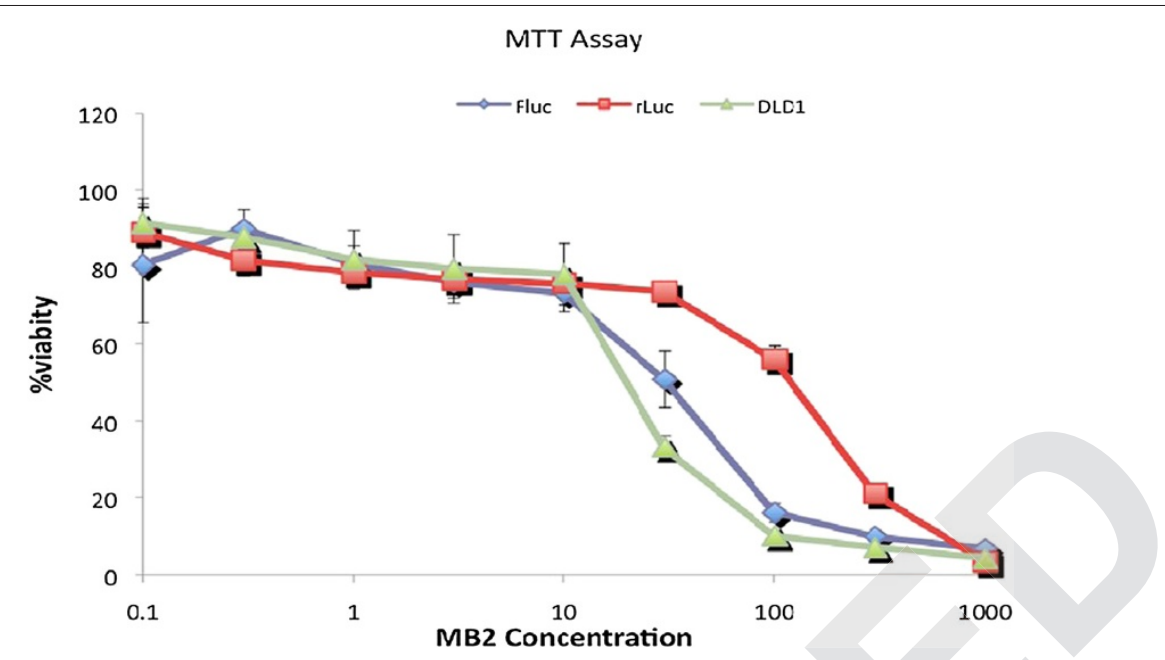

Figure 8 MTT assay result; The effects of MB2 on DLD-1, DLD1/SV-rLuc, and DLD1/SV-FLuc cells exposed to serial dilution of MB2 ranging from .1 $\mathrm{nM}$ to $1 \mu \mathrm{M}$ for 96 hours showing gradual decrease in \% viability with the increasing dose of MB2. Absorbance values were blanked against DMSO and the absorbance of cells exposed to medium only (i.e. no drug added) was taken as $100 \%$ cell viability.

\section{Discussion}

Imaging techniques are emerging as important research tools in the scientific industry, very useful especially in diagnostics which are the main problem of the time. Even though our understanding of functional roles of these reporter genes in cancers is steadily increasing, knowledge about Renilla Luciferase reporter gene GL4.82 and GL4.13 promoter used in colon adenocarcinoma is still largely missing. Hence focused on the characterization of the best transfection technique to get the stable cell line after transfection, which could result in a fine biomarker in targeting colon adenocarcinoma cells. Supporting previous findings that imaging techniques are largely used in tumor studies, cell growth profile of DLD1, DLD1/SV-rLuc Cells and DLD1/SV-FLuc cells were established. Cell lines demonstrated that proliferation levels of DLD1, DLD1/SV-rLuc Cells and DLD1/SV-FLuc cells were significantly same relative to non-tumorigenic cell lines [34,35]. Growth reduction of DLD-1 cells upon transient miR-145 transfection, which implies that miR-145 possesses a tumor-suppressor function in vitro has already been reported [36].

Here, immunocytochemistry has been used as a method of identification of potential targets using two different drugs. It has the advantage over strictly computational target prediction that it is not only based on the presence of a

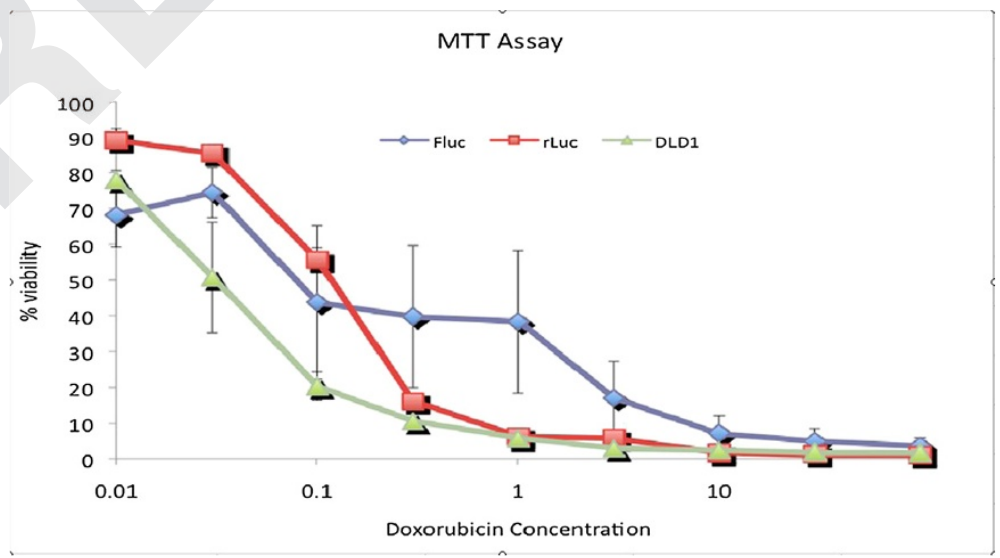

Figure 9 MTT assay result; The effects of Doxorubicin on DLD-1, DLD1/SV-rLuc, and DLD1/SV-FLuc cells exposed to serial dilution of Doxorubicin ranging from $10 \mathrm{nM}$ to $100 \mu \mathrm{M}$ for 96 hours showing gradual decrease in \% viability with the increasing dose of Doxorubicin. Absorbance values were blanked against DMSO and the absorbance of cells exposed to medium only (i.e. no Drug added) was taken as $100 \%$ cell viability. 
seed site and sequence features of the potential target, but takes into account whether the target is expressed in the considered cell line and whether the target is regulated on the transcript level [37-39]. Since this approach is solely based on changes observed on transcript level, targets exclusively regulated by translational repression will not be identified. Many of the targets identification techniques used here have previously been implicated in cancer $[40,41]$. A number of florescence genes with florescence function, many of which have also been associated with colon cancer, were identified as potential biomarkers based on the microarray analysis [42-44]. The cell membrane associated fraction of VANGL1 increases with differentiation and was demonstrated to co-localize with E-cadherin in human colon cells $[45,46]$. Previously reported miR-145 targets including OCT4, SOX2 and KLF4 involved in the promotion of stem cell proliferation were not expressed in DLD- 1 cells $[47,48]$.

Experimental validation of these biomarkers demonstrated a significant success in in-vitro studies as well as in in-vivo [49]. The regulation in luciferase assays further validates that this is the result of direct interactions [50]. The reason of the different effects of luminesce in the different assays is likely due to a lack of direct comparability between these assays [51]. This difference could also be due to other binding factors involved in regulation of the endogenous transcript, as these binding sites are not present in the 3'UTR or cDNA fragments used in the cloned luciferase reporter constructs [52-54].

A number of studies have linked increased use of these biomarkers in cancer studies with increased cell motility and tumor invasion [55]. In conclusion, using a microarray based approach we have identified additional targets for the cancer-associated miRNA miR-145 in colon cancer cells [56]. These transfection techniques could be a milestone in identifying different targets in colon cancers as well as other cancer types [57-59]. As the problem for the early diagnose stays the same in this era we need to have more studies following these lines of the studies which could save time and get very early diagnose of the cancer at the same time.

On the same time we strongly suggest the further use of the same cell lines been transfected in this studies in Orthotopic Xenotransplantation Studies, as we best stable cells were frozen down already. These studies can elaborate the use of such biomarkers in In-Vivo studies.

\section{Conclusions}

Renilla Luciferase reporter gene GL4.82 and GL4.13 promoter Renilla luciferases (rLuc) GL4.82 have emerged as important gene regulators and are recognized as key players in transfection (rLuc) GL4.82 is reported to be down regulated in several cancers, but knowledge of its targets in colon cancer remains limited. To investigate the role of (rLuc) GL4.82 in colon cancer, we have employed imaging based approach to characterize the best transfection technique to get a stable transfected colon DLD1 cell line. Based on the best of its imaging results in-vitro we hereby urge the use of this cell line in Orthotopic Xenotransplantation Studies and in-vivo experiments. DLD1/SV-rLuc cells gained little bit resistance against both drugs; more studies designed for this particular plasmid need to be carrying out to know the reason why they gained that resistance while other transfected line did not.

\section{Methods \\ Materials}

DLD1 (colon adenocarcinoma cells) obtained from European Collection of Cell Cultures Salisbury UK (ECACC ${ }^{\mathrm{m}}{ }^{\mathrm{N}}$ ). DLD1/Sv-Fluc transfected cells obtained from IN HOUSE CELL CULTURE COLLECTION of ICT. Roswell Park Memorial Institute 1640 (RPMI) medium supplemented with, 1\% L-glutamine, 1\% Sodium Pyruvate, $10 \%$ fetal bovine serum (FBS), all purchased from Sigma Aldrich, St. Louis, USA. Hanks Balanced Salt Solution (HBSS), T/E .25\% Trypsin EDTA Solution, Serum free media (SFM), Doxorubicin Hydrochloride, MTT (Thiazolyl Blue Tetrazolium Bromide, Approx 98\% TLC), DMSO (Dimethyl Sulfoxide, $\geq 99.9 \%$ ACS Spectrophotometric grade) and Puramycin dihydrochloride solution $10 \mathrm{mg} / \mathrm{ml}$ also obtained from Sigma Aldrich, St. Louis, USA. Gene Pulser Xcell Machine, Renilla Luciferase reporter gene GL4.82, and GL4.13 promoter obtained from Promega, Madison, USA. Fermentas, Maryland, USA provided $150 \mathrm{mM} \mathrm{NaCl}$, and ExGen 500. Coelenterazine (native coelenterazine), a substrate for Renilla Luciferase from Biotium Hayward, CA (the compound $(1 \mathrm{mg} / \mathrm{ml}$ ) was dissolved in methanol). D-luciferin Firefly potassium salt, a substrate for Fire Fly Luciferase from Xenogen Alameda, CA (A 30-mg/ml stock in PBS was filtered through $0.22 \mu \mathrm{m}$ filters before use). IVIS 50 imaging machine from Calliper Life Sciences, Hopkinton, USA. MB2 (Vascular Disrupting Agent) was taken from in house production of ICT.

\section{Cell lines, culture conditions}

DLD1 cells, DLD1/Sv-Flu previously cultured and DLD1/ SV40-rLuc transfected with Renilla luciferase (rLuc) GL4.82 reporter gene under the control of Simian Virus 40 GL4.18 promoter, cells were maintained in complete RPMI 1640 medium and incubated in humidified incubator at $37^{\circ} \mathrm{C}$ and $5 \% \mathrm{CO}_{2}$ level. Passage of all types of cells was always done by seeding in complete RPMI 1640, incubating at $37^{\circ} \mathrm{C}$ and $5 \% \mathrm{CO}_{2}$ level, washing twice by $10 \mathrm{ml} /$ wash 
Table 1 ExGen500's Volume used for transfection

\begin{tabular}{lll}
\hline Sample & $\begin{array}{l}\text { Amount of } \\
\text { DNA }\end{array}$ & $\begin{array}{l}\text { Volume Of ExGen500 } \boldsymbol{\mu l} \\
\text { at equivalents }\end{array}$ \\
\hline DLD1/SV-rLuC/ExGen1 & $1 \mu \mathrm{g}$ & $8.23 \mu \mathrm{l}$ \\
\hline DLD1/SV-rLuC/ExGen2 & $1 \mu \mathrm{g}$ & $9.87 \mu \mathrm{l}$ \\
\hline DLD1/SV-rLuC/ExGen3 & $1 \mu \mathrm{g}$ & $11.52 \mu \mathrm{l}$ \\
\hline
\end{tabular}

HBSS and counting manually with the help of haemocytometer after trypsinization.

\section{Transfection of the cells}

Renilla Luciferase reporter gene GL4.82 (Figure 2) and SV40 GL4.13 (Figure 1) promoter been used to make the reporter gene by cloning SV40 region from GL4.13 into the NheI \& Hind III site of GL4.82 made SV40-RLuc as a vector reporter to transfect the DLD1 cells [60].

\section{Transfection methods}

Two different techniques of transfection;
I. Electroporation
II. ExGen500

\section{Electroporation}

$1 \times 10^{7}$ cells $/ \mathrm{ml}$ were used for Electroporation Transfection, so resuspended the required concentration of the cells in $400 \mu \mathrm{l}$ of serum free media (SFM) after trypsinization of the cells. Transferred the cell suspension to the $2 \mathrm{~mm}$ vial. $0.88 \mu \mathrm{g} / \mathrm{ml} \mathrm{SV40-RLuc} \mathrm{were} \mathrm{added} \mathrm{to} \mathrm{each} \mathrm{sample} \mathrm{(needed}$ $20 \mu \mathrm{g}$ of Plasmid in $400 \mu \mathrm{l}$ of cell suspension). Gene Pulser Xcell Machine was used for electroporation. Two methods of electroporation were used;

Exponential electroporation; the machine was set at voltage 250volts, Capacitance 1000volts, and resistance $\infty$. Sample 1 was electroporated and these cells were named DLD1/SV-rLuc/ELec1.

Square Wave Method; the machine was set at voltage 250volts, Pulse Length $10 \mathrm{~nm}$, and Number of Pulse 1. Sample 2 was electroporated and these cells were named DLD1/SV-rLuc/ELec2. Following the transfection, Cells were transferred in to T25 flasks and incubated in humidified incubator at $37^{\circ} \mathrm{C} 5 \% \mathrm{CO}_{2}$.

\section{ExGen500 Transfection}

Initially, we recommend the use of $1 \mathrm{ug}$ of DNA and $3.3 \mathrm{ul}$ (6 equivalents) of ExGen 500 per well of 6-well plate. Cells were plated in 6 well plates at $5 \times 10^{4}$ cells/well and incubated overnight at $37^{\circ} \mathrm{C} 5 \% \mathrm{CO}_{2}$ level. $150 \mathrm{mM}$ $\mathrm{NaCl}$ solution was made up. The ExGen 500 and DNA complex was made by adding $1 \mu \mathrm{g}$ of SV40-RLuc in to $100 \mu \mathrm{l}$ of $150 \mathrm{mM} \mathrm{NaCl}$, vortaxing gently and spinning down and then adding ExGen 500 at the concentrations shown in (Table 1). Following this, the solution was mixed immediately for 10 second then incubated for 10 minutes at room temperature. Then $100 \mu \mathrm{l}$ of each sample was added to each well containing $3 \mathrm{ml}$ complete RPMI 1640 respectively. Then plate was incubated at $37^{\circ} \mathrm{C}$ and $5 \%$ $\mathrm{CO}_{2}$ level for 48 hours. Colonies were visible after 2 to 3 weeks. Colonies were picked using sterile cloning rings and expanded to form sub lines.

\section{Puramycin selection/cloning}

To select the cells expressing the required DNA vector (Figure 1), all types of cell were treated with $50 \mu \mathrm{g} / \mathrm{ml}$ of Puramycin because SV40-RLuc is Puramycin resistant that works as selection marker. Optimal concentration for puramycin was tested earlier at different concentrations with normal DLD1 cells data not included here. So, purely transfected cells expressing the required DNA vector (Figure 1), sustained within the puramycin were harvested and plated in Petri dishes and 96 well plates at $10 \mathrm{cells} / \mathrm{ml}$ following the procedure described earlier. Plates were incubated at $37^{\circ} \mathrm{C} 5 \% \mathrm{CO}_{2}$ level for $2-3$ days. Single cell clones were selected in both, Petri dishes and 96 well plates for imaging. Single cell best observed clones in 96 well plates were imaged directly. While best clones from Petri dishes were passaged to the 24 well plates using method descried earlier.

\section{Serial dilutions}

To check the ratio of bioluminescence and cell numbers both DLD1/SV-FLuc and DLD1/SV-rLuc cells were serially diluted. Each type of cells were serially diluted at the concentrations ranging from $1 \times 10^{4}$ cells/well to $1 \times 10^{6}$ cells/well and DLD1/SV-FLuc at the concentrations ranging from $5 \times 10$ cells/well to $1 \times 10^{6}$ cells/well was plated in 96 well plates. Incubated overnight at $37^{\circ} \mathrm{C} 5 \% \mathrm{CO} 2$ level for imaging.

Table 2 Drug concentrations of MB2 and Doxorubicin used in MTT assay

\begin{tabular}{|c|c|c|c|c|c|c|c|c|c|c|}
\hline \multirow{2}{*}{$\begin{array}{l}\text { Blank } \\
\text { Blank }\end{array}$} & \multirow{2}{*}{$\begin{array}{l}\text { Control } \\
\text { Control }\end{array}$} & \multicolumn{9}{|c|}{ MB2 drug concentration } \\
\hline & & $.1 \mathrm{nM}$ & $.3 \mathrm{nM}$ & $1 \mathrm{nM}$ & $3 \mathrm{nM}$ & $10 \mathrm{nM}$ & $30 \mathrm{nM}$ & $100 \mathrm{nM}$ & $300 \mathrm{nM}$ & $1 \mu \mathrm{M}$ \\
\hline Blank & Control & \multicolumn{9}{|c|}{ Doxorubicin Drug Concentration } \\
\hline Blank & Control & $10 \mathrm{nM}$ & $30 \mathrm{nM}$ & $100 \mathrm{nM}$ & $300 \mathrm{nM}$ & $1 \mu \mathrm{M}$ & $3 \mu \mathrm{M}$ & $10 \mu \mathrm{M}$ & $30 \mu \mathrm{M}$ & $100 \mu \mathrm{M}$ \\
\hline
\end{tabular}




\section{Imaging and quantification of bioluminescence data}

The in vivo Imaging System (IVIS), consists of a cooled camera (CCD) mounted on a light- tight chamber (dark box), a camera controller, a camera cooling system, and a Windows based computer system, were used for data acquisition and analysis. Each 96/24-well plate sample was placed in the specimen chamber mounted with the CCD camera cooled to $-90^{\circ} \mathrm{C}$, with a field of view set at $25 \mathrm{~cm}$ above the sample shelf. The photon emission, transmitted from cell samples was measured in $\mathrm{p} / \mathrm{sec} / \mathrm{cm} 2 / \mathrm{sr}$. The bioluminescence color images were viewed using the living image software overlay (Xenogen). Bioluminescence was measured for the plates set up for imaging using substrate $50 \mu \mathrm{g} / \mathrm{ml}$ Coelenterazine for RLuc cells and $30 \mathrm{mg} / \mathrm{ml}$ stock solution of D-Luciferin at 1: 200 dilution for FLuc cells. To check the effect of lower concentration of Coelenterazine, $25 \mu \mathrm{g} / \mathrm{ml}$ of Coelenterazine was used to image ring cloning and 96 well plate cloning. Images were taken within the $10 \mathrm{sec}$ of the Coelenterazine addition to the cells, due to the quick nature of the reaction. Coelenterazine was tested alone1st in blank 2nd in only media.

\section{Growth curve}

Growth curves were determined to ensure that transfected cells show no difference to normal cells in their proliferation activity. Normal DLD1 cells, DLD1/SV-rLuc Cells and DLD1/SV-FLuc cells were seeded at $5 \times 10^{4} \mathrm{cells} / \mathrm{ml}$. Fourteen flasks of each line were seeded. To count, cells were washed with Hanks, trypsinized, centrifuged, and resuspended in $5 \mathrm{ml}$ of media and then counted manually using Haemocytometer every day for 7 days. Two flask of each type of cells were used every day to have precise average count of the cell.

\section{MTT assay}

The MTT assay was done to check that transfected and normal cells had same Chemosensitivity (transfection has not changed their nature to react with the chemicals). In brief, normal DLD1, DLD1/SV-rLuc Cells and DLD1/ SV-FLuc cells were seeded at $1 \times 10^{5}$ cells $/ \mathrm{ml}$ into 96 well plates. Column 1 containing culture medium $200 \mu \mathrm{l} /$ well, only to blank the Spectrophotometer. Some drugs affect the optical density (OD) of the medium and require a separate blank. Colum 2 containing $200 \mu \mathrm{l} /$ well only cell suspension but no drug exposure serves as control wells to calculate the control cell survival percentage rest of the plate cultivated with $180 \mu \mathrm{l} /$ well of cell suspension. The cells then left to adhere for $24 \mathrm{~h}$ in incubator at $37^{\circ} \mathrm{C} 5 \%$ $\mathrm{CO} 2$ level. Next day, serial dilutions of both drugs were prepared (Table 2).

MB2 ranges from $1 \mu \mathrm{M}$ to $.1 \eta \mathrm{M}$ and Doxorubicin ranging from $100 \mu \mathrm{M}$ to $10 \eta \mathrm{M}$, and added $20 \mu \mathrm{l}$ of each dilution to the plates respectively leaving Blank and control with no drug. The plates were incubated at $37^{\circ} \mathrm{C}$ with 5\% CO2 level for 96 hours. MTT stock solution $5 \mathrm{mg} / \mathrm{ml}$ was prepared in distilled water. Stock solution of MTT was then diluted in complete RPMI 1640 at $1 /$ 10 ratio. All the media from the plates were removed and MTT solution $200 \mu \mathrm{l} /$ well was added in each well leaving blank. The plates were incubated for 4 hours at $37^{\circ} \mathrm{C}$ with $5 \% \mathrm{CO} 2$. MTT was removed from the plates very carefully and $150 \mu \mathrm{l}$ of DMSO was added. Finally the absorbance at $540 \mathrm{~nm}$ of the plates was read with the Tecan plate reader. MTT assay were done in triplicate. Absorbance values were blanked against DMSO and the absorbance of cells exposed to medium only i.e. no Drug added was taken as $100 \%$ cell viability i.e. the control.

\section{Freezing down the cells}

The best clones resulting high intensity of bioluminescence were washed with hanks, trypsinized, centrifuged and resuspended in $1 \mathrm{ml}$ of complete RPMI 1640. Cells suspension was transferred to the $1.5 \mathrm{ml}$ vials with 1:10 of DMSO and stored in freezer at $-80^{\circ} \mathrm{C}$ for future use.

\section{Competing interests}

The authors declare that they have no competing interests.

\section{Authors' contributions}

MRS and SS carried out the reporter gene cloning SV40 to make SV40-RLuc as a vector reporter to transfect the DLD1 cells and biochemical characterizations, MAA performed transfection studies. IY and AW carried out imaging and quantification of bioluminescence data. All authors have read and approved the final manuscript.

\section{Acknowledgments}

This research work is collaborative research work conducted by Cell Culture Lab, Institute of Cancer Therapeutics, Bradford University, UK, Department of Chemistry, University of Malaya and Department of Chemistry, The Islamia University of Bahawalpur, Pakistan. The research was supported by grant from the Cell Culture Lab, Institute of Cancer therapeutics, Bradford University, UK, and by UM research grants PV039-2011.

\section{Author details}

${ }^{1}$ Guy Hilton Research Centre, Keele University, Staffordshire, UK. ${ }^{2}$ Department of Chemistry, University of Malaya, 50603 Kuala Lumpur, Malaysia. ${ }^{3}$ Department of Geology, University of Malaya, 50603 Kuala Lumpur, Malaysia. ${ }^{4}$ Department of Chemistry, The Islamia University of Bahawlapur, Bahawlapur 63100, Pakistan.

Received: 3 May 2012 Accepted: 2 July 2012

Published: 18 July 2012

\section{References}

1. Kalabis J, Rosenberg I, Podolsky DK (2006) Vangl1 protein acts as a downstream effector of intestinal trefoil factor (ITF)/TFF3 signaling and regulates wound healing of intestinal epithelium. J Biol Chem 281:6434-6441

2. Horvath CM (2000) STAT proteins and transcriptional responses to extracellular signals. Trends Biochem Sci 25:496-502

3. Johnson M, Sharma M, Henderson BR (2009) IQGAP1 regulation and roles in cancer. Cell Signal 10:1471-1478

4. Sandelin A, Alkema W, Engstrom P, Wasserman WW, Lenhard B (2004) JASPAR: an open- access database for eukaryotic transcription factor binding profiles. Nucleic Acids Res 32:D91-D94

5. Chen HC, Chen GH, Chen YH, Liao WL, Liu CY (2009) MicroRNA deregulation and pathway alterations in nasopharyngeal carcinoma. Br J Cancer 100:1002-1011 
6. Gramantieri L, Ferracin M, Fornari F, Veronese A, Sabbioni S (2007) Cyclin G1 is a target of miR-122a, a microRNA frequently down-regulated in human hepatocellular carcinoma. Cancer Res 67:6092-6099

7. Nicolau B, Catherine C, Anna LB, Francois BLE, Stefan Z, Rainer K, Vincet D (2007) Review Article in vivo mouse imaging and spectroscopy in drug discovery. Nanomed Nanobiotech 20:154-185

8. Meng Y, Eugene B, Jin-Wei W, Ping J, Xiaoen W, Fang-Xian S, Michael B, Moossa AR, Sheldon P, Robert MH (2002) Direct external imaging of nascent cancer, tumor progression, angiogenesis, and metastasis on internal organs in the fluorescent orthotopic model. PNAS 99:3824-3829

9. Lin Y, Weissleder R, Tung CH (2003) Synthesis and properties of sulfhydrylreactive near infrared cyanine fluorochromes for fluorescence imaging. Mol Imaging 2:87-92

10. Nathan CS, George HP, Michael WD (2007) Advances in fluorescent protein technology. J Cells Sc 120:4247-4260

11. Contage PR (2002) Whole animal cellular and molecular imaging to accelerate drug development. Drug Discov Today 7:555-562

12. Contag CH (1997) Living mammals using a Bioluminesce reporter. Photochem Photobiol 66:523-531

13. Ruxana TS, Timothy SB (2005) Bioluminescence imaging. Proc Am Thorac Soc 2:537-540

14. Wilson T, Hastings JW (1998) Bioluminescence. Annu Rev Cell Dev Biol 14:197-230

15. de Wet JR, Wood KV, Helinski DR, DeLuca M (1985) Cloning of firefly luciferase CDNA and the expression of active luciferase in Escherichia coli. Proc Natl Acad Sci USA 82:7870-7873

16. Selden RF (2001) Transfection using DEAE-dextran. Chap 10. 10.14

17. Joseph S, David WR (2006) Calcium-phosphate-mediated transfection of eukaryotic cells with plasmid DNAs: protocols. doi:10.1101/pdb.prot3871

18. Felgner P (1987) L: A highly efficient, lipid-mediated DNA-transfection procedure. Proc Natl Acad Sci USA 21:7413-7417

19. Straubinger RM, Duzgunes N, Papahadjopoulos D (1991) pH-sensitive liposomes: introduction of foreign substances into cells. FEBS Lett 179:713-730

20. Graessmann A, Wolf H, Bornkamm GW (1980) Expression of Epstein-Barr virus genes in different cell types after microinjection of viral DNA. Proc Natl Acad Sci USA 77:433-436

21. Mello CC, Kramer JM, Stinchcomb D, Ambros V (1991) Efficient gene transfer in C.elegans: extrachromosomal maintenance and integration of transforming sequences. EMBO J 10:3959-3970

22. Kleber S, Sancho-Martinez I, Wiestler B, Beisel A, Gieffers C (2008) Yes and PI3K bind CD95 to signal invasion of glioblastoma. Cancer Cell 13:235-248

23. Thomas SM, Brugge JS (1997) Cellular functions regulated by Src family kinases. Annu Rev Cell Dev Biol 13:513-609

24. Pena SV, Melhem MF, Meisler Al, Cartwright CA (1995) Elevated c-yes tyrosine kinase activity in premalignant lesions of the colon. Gastroenterology 108:117-124

25. Christoffersen NR, Shalgi R, Frankel LB, Leucci E, Lees M (2010) p53independent upregulation of miR-34a during oncogene-induced senescence represses MYC. Cell Death Differ 17:236-245

26. Arvidsson S, Kwasniewski M, Riano-Pachon DM, Mueller-Roeber B (2008) QuantPrime-a flexible tool for reliable high-throughput primer design for quantitative PCR. BMC Bioinforma 9:460-465

27. Gentleman R, Carey V, Huber W, Hu T, Irizarry R (2005) Bioinformatics and computational biology solutions using $R$ and bioconductor. Springer, New York, p 473

28. Huber W, von Heydebreck A, Sultmann H, Poustka A, Vingron M, Huber W, von Heydebreck A, Sultmann H, Poustka A, Vingron M (2002) Bioinformatics 18(Suppl 1S):96-104

29. Schaffner W (1980) Direct transfer of cloned genes from bacteria to mammalian cells. Proc Natl Acad Sci USA 77:2163-2167

30. Purves WK (2001) Life: the science of biology. Sinauer Associates, pp 316-317

31. Nickoloff JA (1995) Preface. In: Nickoloff JA (ed) Electroporation protocols for microorganisms. Humana Press, Totowa, New Jersey, pp v-vi

32. Withers HL (1995) Direct plasmid transfer between bacterial species and electrocuring. In: Nickoloff JA (ed) Electroporation protocols for microorganisms. Humana Press, Totowa, New Jersey, pp 47-54
33. Weaver JC (1995) Electroporation theory: concepts and mechanisms. In: Nickoloff JA (ed) Electroporation protocols for microorganisms. Humana Press, Totowa, New Jersey, pp 1-26

34. Kelley RL, Meller VH, Gordadze PR, Roman G, Davis RL, Kuroda MI (1999) Epigenetic spreading of the Drosophila dosage compensation complex from roX RNA genes into flanking chromatin. Cell 98:513-522

35. Niall S, Ray G, Jean G (2009) Are animal models predictive for humans? Philos Ethics Humanit Med 4:2

36. Weber M, Davies JJ, Wittig D, Oakeley EJ, Haase M, Lam WL, Schubeler D (2005) Chromosome-wide and promoterspecific analyses identify sites of differential DNA methylation in normal and transformed human cells. Nat Genet 37:853-862

37. Rakyan VK, Down TA, Thorne NP, Flicek P, Kulesha E, Gra FS, Tomazou EM, Backdahl L, Johnson N, Herberth M, Howe KL, Jackson DK, Miretti MM, Fiegler H, Marioni JC, Birney E, Hubbard TJ, Carter NP, Tavare S, Beck S (2008) An integrated resource for genome-wide identification and analysis of human tissue-specific differentially methylated regions (tDMRs). Genome Res 18:1518-1529

38. Lister R, Pelizzola M, Dowen RH, Hawkins RD, Hon G, Tonti-Filippini J, Nery JR, Lee L, Ye Z, Ngo QM, Edsall L, Antosiewicz-Bourget J, Stewart R, Ruotti V, Millar AH, Thomson JA, Ren B, Ecker JR (2009) Human DNA methylomes at base resolution show widespread epigenomic differences. Nature 462:315-322

39. Margueron R, Reinberg D (2010) Chromatin structure and the inheritance of epigenetic information. Nat Rev Genet 11:285-296

40. Russell WMS, Burch RL (1959) The principles of humane experimental technique. Methuen, London

41. Van den Heuvel MJ, Dyan AD, Shillaker RO (1987) Evaluation of the BTS approach to the testing of substances and preparations for their acute toxicity. Hum Toxicol 5:151-157

42. Scott KL (2005) Advances in imaging mouse tumour models in vivo. J Pathol 205:194-205

43. Santoro MM, Samuel T, Mitchell T, Reed JC, Stainier DY (2007) Birc2 (clap1) regulates endothelial cell integrity and blood vessel homeostasis. Nat Genet 39:1397-1402

44. Smyth G (2005) Limma: linear models for microarray data. In: Gentleman RCV, Dudoit S, Irizarry R, Huber W, Gentleman RCV, Dudoit S, Irizarry R, Huber W (ed) Bioinformatics and computational biology. Solutions using R and Bioconductor, Springer, New York, pp 397-420

45. Xu N, Papagiannakopoulos T, Pan G, Thomson JA, Kosik KS (2009) MicroRNA-145 regulates OCT4, SOX2, and KLF4 and represses pluripotency in human embryonic stem cells. Cell 137:647-658

46. Cordes KR, Sheehy NT, White MP, Berry EC, Morton SU (2009) miR-145 and miR-143 regulate smooth muscle cell fate and plasticity. Nature 460:705-710

47. Xin M, Small EM, Sutherland LB, Qi X, McAnally J (2009) MicroRNAs miR-143 and miR-145 modulate cytoskeletal dynamics and responsiveness of smooth muscle cells to injury. Genes Dev 23:2166-2178

48. Liu X, Sempere LF, Galimberti F, Freemantle SJ, Black C (2009) Uncovering growth- suppressive MicroRNAs in lung cancer. Clin Cancer Res 15:1177-1183

49. Akao Y, Nakagawa Y, Naoe T (2006) MicroRNAs 143 and 145 are possible common onco- microRNAs in human cancers. Oncol Rep 16:845-850

50. Wieder J, Soloway MS (1998) Incidence, etiology, location, prevention, and treatment of positive surgical margins after radical prostatectomy for prostate cancer. J Urol 160:299-315

51. Barraclough J, Hodgkinson C, Hogg A, Dive C, Welman A (2007) Increases in c-Yes expression level and activity promote motility but not proliferation of human colorectal carcinoma cells. Neoplasia 9:745-754

52. Joseph S (2007) Preclinical development of molecularly targeted agents in oncology, pp 707-772

53. Michael RB, Kenneth DP (1995) Some practical considerations and applications of the national cancer Institute in vitro anticancer drug discovery screen. Drug Develop Res 34:91-109

54. Angelike MB, Heinz HF (2002) Screening using animal system. Drug Develop Res 16:285-289

55. Wang X, Tang S, Le SY, Lu R, Rader JS (2008) Aberrant expression of oncogenic and tumor-suppressive microRNAs in cervical cancer is required for cancer cell growth. PLoS One 3:e2557

56. Grimson A, Farh KK, Johnston WK, Garrett-Engele P, Lim LP (2007) MicroRNA targeting specificity in mammals: determinants beyond seed pairing. Mol Cell 27:91-105 
57. Lim LP, Lau NC, Garrett-Engele P, Grimson A, Schelter JM (2005) Microarray analysis shows that some microRNAs downregulate large numbers of target mRNAs. Nature 433:769-773

58. Nielsen CB, Shomron N, Sandberg R, Hornstein E, Kitzman J (2007)

Determinants of targeting by endogenous and exogenous microRNAs and siRNAs. RNA 13:1894-1910

59. Sahin U, Blobel CP (2007) Ectodomain shedding of the EGF-receptor ligand epigen is mediated by ADAM17. FEBS Lett 581:41-44

60. Francois P (2005) Tumor and Cancers in Graeno-Roman Times 91:4

doi:10.1186/1752-153X-6-69

Cite this article as: Siddique et al.: Retracted: Luciferase-transfected

colon adenocarcinoma cell line (DLD-1) for use in Orthotopic

Xenotransplantation studies. Chemistry Central Journal 2012 6:69.

\section{Publish with ChemistryCentral and every scientist can read your work free of charge}

"Open access provides opportunities to our colleagues in other parts of the globe, by allowing anyone to view the content free of charge."

W. Jeffery Hurst, The Hershey Company.

- available free of charge to the entire scientific community

- peer reviewed and published immediately upon acceptance

- cited in PubMed and archived on PubMed Central

- yours - you keep the copyright

Submit your manuscript here:

http://www.chemistrycentral.com/manuscript/
hubmit your manuscript here:<smiles>c1ccccc1</smiles> 